\title{
PEDAGOGICAL CONCEPTIONS AND PRACTICES OF YOUTH AND ADULT EDUCATION TEACHERS IN THE INCLUSION OF STUDENTS WITH INTELLECTUAL DISABILITY
}

\author{
Graciliana Garcia Leite, \\ Juliane Ap. P. Perez Campos \\ Graduate Program in Special Education, \\ Federal University of São Carlos, \\ Brazil
}

\begin{abstract}
:
Background: Youth and Adult Education (YAE) is a teaching modality in Brazil aimed at people who have not had access to mainstream school or not completed their schooling. Objective of the study was to characterise the pedagogical practices of teachers in the mainstream classroom and special education, working with students with intellectual disabilities at YAE. Method: Qualitative descriptive approach. Observations in classrooms and interviews with teachers. Data consolidated by content analysis and arranged in themes. Results: Teachers have difficulty meeting the student's specific needs and developing pedagogical resources and strategies to promote access to knowledge. Conclusions: Need exists for greater collaboration between regular and special education teachers to organize the pedagogical planning enabling more assertive pedagogical practices.
\end{abstract}

Keywords: special education, youth and adult education, intellectual disability, pedagogical practice

\section{Introduction}

Youth and Adults Education (YAE) in Brazil and school inclusion in the areas of YAE is a topic not much discussed in Brazil. It seems that such invisibility is related to the lack of attention given to the population. Special Education (SE) is a teaching process aimed at students with disabilities, global developmental disorders and high skill/gift levels (Brasil, 2008). Like YAE, SE in Brazil was organised in a social perspective and with compensatory actions due to the population's lack of access to formal education (Cabral, Bianchini, \& Gonçalves, 2018). Both teaching methods are legally articulated (Brasil, 1996, 2008).

i Correspondence: email gracilianagl@gmail.com; gracilianagarcia@estudante.ufscar.br

${ }^{i}$ This article presents part of the results obtained in the master's thesis of the first author. 
YAE is a complex teaching method that goes beyond educational issues. Until recently, it was considered that this education was precisely a process of literacy, that is, teaching young people and adults how to read and write, who for different reasons did not have access to school or had access to school and did not finish their studies. Currently, the discussions add that the teacher who works at YAE needs to incorporate elements that allow him to critically reflect on his practice, and thus expand the teaching process, valuing the history of the students' lives and the social aspects present in this context (Strelhow, 2010).

The school inclusion of students with disabilities in YAE has been increasing in recent years and is not restricted to students who did not have access to school. According to Siems (2012), the justification for this movement is due to the fact that public policies prioritise enrolment, preferably in mainstream classrooms, expanding the access of these students to YAE spaces as well. However, the literature points out that many students with intellectual disabilities have been referred to YAE, popularly called "Special YAE" and, many times, these students stay for a long time in mainstream classes and do not acquire learning to read and write (Pletsch, 2014).

According to the guidelines of the National Policy on Special Education in the Perspective of Inclusive Education (Brasil, 2008b), all students included in mainstream schools, that is, enrolled in mainstream classes, must receive a pedagogical complementation offered by Specialised Educational Service (SES), with the attendance of a specialist teacher, preferably in a resource room on the shift opposite their normal school hours. According to Resolution No. 4 (Brasil, 2009):

Art. 2 'AEE's'[SES's] function is to complement or supplement the student's training through the availability of services, accessibility resources and strategies that eliminate the barriers that prevent their full participation in society and the development of their learning.

"The purpose of the SES is to collaborate so that the student with disabilities is attended to in their educational specificities, articulating with the curriculum proposal, in a way that guarantees their participation in mainstream education." (Cezário, 2019, p. 46). Other aspects can also be developed in the SES that will provide greater autonomy for this student after the end of schooling. It is agreed with Redig (2019) that the goal at school is not only certification and continuity of studies, but to provide students with training that enables them to enter the world of work and adulthood.

Regarding the performance of SES teachers in YAE, Cezário (2019) emphasises the need for teachers to have adequate and continuous training and communication between teachers in the mainstream classroom and special education. According to Cezário (2019, p. 49), collaboration in YAE between teachers will help students to advance "[...] in the achievement of learning and social interactions, in family life and contributing to enter or cooperate with skills for the labour market, socio-cultural participation and achieving rights like other people". 
Even with all the advances in legislation in favour of inclusive education and constructed scientific knowledge, it is observed that school practices and school culture have not changed. Such a condition causes damage to the teaching and learning process of the students included, especially those with intellectual disabilities (Pletsch \& Glat, 2012).

That said, it is necessary to offer access to permanence in these spaces and the resources for the acquisition of scientific knowledge by students with intellectual disabilities, therefore, it is essential that schools analyse their procedures on teaching and learning processes assuming aspects of the syllabus, activity planning, time and student learning (Glat \& Pletsch, 2012).

According to Bins (2013), many teachers have difficulties in the process of including students with intellectual disabilities, claiming lack of training and lack of knowledge about the learning process of these subjects. Teachers point out that these students, in addition to not responding to content in an expected manner, also escape the expected student standard by limiting the teacher's work.

Therefore, reflecting on the teaching and learning process of young people and adults with intellectual disabilities requires overcoming the mistaken perception of the incapacity of these subjects, the low expectations of learning and the processes of infantilisation, often still present in the school context to recognise their potentials and their experiences. The present work is supported by the study by Vargas and Gomes (2013, p.452) when defending that the school should consider the educational content according to the students' reality and experience, because "[...] the pedagogical practice consists in an investigation of thinking and in the discussion of world views expressed in the different ways of relating to others and to objects of knowledge".

In this sense, when reflecting on the inclusion of students with intellectual disabilities included in the YAE, it is necessary to understand which pedagogical practices must be adopted to make the acquisition of knowledge possible, considering the condition of each student and their perspectives of the teaching process and learning and social aspects. Some studies carried out in the context of YAE directed at students with intellectual disabilities indicate that, often, the pedagogical practices adopted by teachers for students with intellectual disabilities in YEA are not consistent with the profile and its main demands. In the understanding of Dantas (2012) and Freitas (2014), it is necessary to rethink the pedagogical practices for students with disabilities in YEA, eliminating childish content, based on the assumption of their inability to assume adult roles.

\section{Objectives}

Thus, the objective of this study was to characterise the pedagogical practices of teachers in the mainstream classroom and in special education who work with students with intellectual disabilities at YAE. 


\section{Method}

\subsection{Study design}

The approach used in this study was qualitative of a descriptive nature, interviews were conducted to collect and analyse information, and the school environment was observed, for a better understanding of the facts and the way they occurred in their investigated context.

\subsection{Setting}

The location of this study was in a city of the Sao Paulo state in Brazil. The study was carried out between the months from March 2019 to May 2019.

\subsection{Participants}

Participants were teachers from the mainstream classroom of YAE and teachers of special education who worked at YAE with students diagnosed with intellectual disabilities. They were selected based on their education and qualification and the number of years of experiences. Also, their gender was considered. Another participant was a student with an intellectual disability who attended a mainstream classroom.

\subsection{Data collection instruments}

For data collection, the Observation Script of Practices of the Professor of the Mainstream Classroom and the Professor of the Multifunctional Resources Room adapted from (Reis, 2011) was used. Through the observation technique, it was possible to access the practices applied in the classroom. Thus, we seek to observe the teacher-student relationship with intellectual disabilities, methodological procedures and use of resources, teaching strategies, curricular adaptation, and student participation during classes, among other aspects.

The protocols for observation in the mainstream classroom and in the multifunctional resource room were used. Through the observation technique, it was possible to access the practices applied in the classroom. This technique allows to discover how something effectively occurs (Flick, 2009).

The interview scripts went through the review of researchers with experience and knowledge in adult education with students with intellectual disabilities to verify that the scripts were in accordance with the objectives of the study and appropriate participants.

\subsection{Data collection procedure (study size)}

In order to carry out the study the 12 observations of 3 hours long were conducted in the mainstream classroom and 5 observations of 60 minutes long were conducted in the multifunction resources room. Subsequently, individual interviews with teachers were carried out. The interviews with participating teachers of the study in order to 
complement other techniques of data collection, as well as allowing the deepening of knowledge about certain aspects.

\subsection{Data analysis procedure}

The data obtained were analysed by content analysis, that is, it combines the elements with common characteristics related to each other, organised into thematic categories. This method can emphasise both organisation and rich description of the data set and theoretically informed interpretation of meaning. This process was carried out in three stages: pre-analysis, organization of the material and interpretation of the results (Franco, 2008).

In the pre- analysis phase, after the transcription of the interviews and the records of the observations noted in the field diaries, there was a fluctuating reading of the material in order to identify the ideas put in place that were relevant to the specific objectives of the research (Franco, 2008).

In the process of processing the results, the inference and interpretation of the set of each thematic category was carried out. The realisation of this strategy allowed us to analyse both the data obtained through interviews and observations made, thus enabling understand aspects important to achieve the objectives of this study.

For the analysis of the observations, the observation protocol records were read, while the audio recorded interviews were transcribed in full and read. After the information review, these data were organised into subcategories as shown in Table 1.

Table 1: Study category and subcategories 1

\begin{tabular}{|l|l|}
\hline Category & Subcategories \\
\hline $\begin{array}{l}\text { Characterisation of the pedagogical practices of } \\
\text { the teacher of the mainstream classroom of YAE } \\
\text { and of the Teacher of Special Education. }\end{array}$ & $\begin{array}{l}\text { Organisation and teaching performance in the } \\
\text { mainstream classroom. }\end{array}$ \\
& $\begin{array}{l}\text { Organisation and teaching performance in the } \\
\text { multifunctional resource room. }\end{array}$ \\
& Teaching articulation at YAE. \\
\hline
\end{tabular}

Source: Prepared by the author.

Table 1 shows how all items of analysis related to the teachers' pedagogical practices were organised.

\section{Results}

\subsection{Study characteristics}

The results described below refer to the pedagogical practices of teachers who work in the context of YAE with students with intellectual disabilities. The data describe how the planning and development of classes and activities take place, the classroom routine, the 
most used strategies and materials, and the interaction between the Mainstream Classroom Teacher and the Special Education Teacher.

\subsection{Participants}

The list of participants is presented in the Table 2 and Table 3 below.

Table 2: Attributes of the teachers participating in the study

\begin{tabular}{|l|c|c|c|c|}
\hline Teacher Type & Age & Operating Area & Time in teaching & Professional qualification \\
\hline Mainstream & 52 & $\begin{array}{c}\text { Mainstream } \\
\text { Classroom }\end{array}$ & $\begin{array}{c}\text { 26 years working } \\
\text { in elementary } \\
\text { school, 13 years in } \\
\text { YAE. }\end{array}$ & $\begin{array}{c}\text { Normal and Higher Teaching, } \\
\text { Pedagogical Complementation and } \\
\text { Degree in Sciences. }\end{array}$ \\
\hline $\begin{array}{l}\text { Special } \\
\text { Education }\end{array}$ & 43 & $\begin{array}{c}\text { Multifunctional } \\
\text { Resource Room }\end{array}$ & $\begin{array}{c}\text { Graduated for 12 } \\
\text { years, she has been } \\
\text { working at SES for } \\
10 \text { years. }\end{array}$ & $\begin{array}{c}\text { Graduation in Pedagogy with } \\
\text { qualification in mental disability and } \\
\text { specialization in clinical and } \\
\text { institutional psych pedagogy. }\end{array}$ \\
\hline
\end{tabular}

Source: Elaborated by the researcher.

Table 2 presents the general attributes of the participating teachers. In addition, the Mainstream Classroom Teacher is 52 years old; she has a degree from the University of São Paulo - USP. The Special Education Teacher is 43 years old, has a degree from Universida de Estadual Paulista - UNESP.

Table 3: Attributes of a student participating in the study

\begin{tabular}{|c|c|c|c|}
\hline Student's Name & Age & Grade & Student's Description \\
\hline Paula & 29 & $\begin{array}{c}\text { Elementary I } \\
\text { Term } 2\end{array}$ & $\begin{array}{l}\text { Diagnosis: intellectual disability. } \\
\text { She started schooling in a rural school at the age of } 6 \text {; } \\
\text { She was referred to the Special School in the } 1^{\text {st }} \text { grade of } \\
\text { elementary school; } \\
\text { She only attended the Special School until 2017; } \\
\text { In 2017, the Special School asked the family of the student to } \\
\text { enrol her into the regular school; } \\
\text { The student is not yet literate; } \\
\text { She can to read simple words; } \\
\text { Student is very communicative and participates in } \\
\text { class activities and frequently makes comments relating to } \\
\text { everyday life; } \\
\text { Teacher reports difficulty and resistance to group activities; } \\
\text { Performs simple addition and subtraction operations; } \\
\text { However, the teachers report difficulties in learning the math } \\
\text { content and oscillation "days when she works better, and } \\
\text { others do not". }\end{array}$ \\
\hline
\end{tabular}

Source: Elaborated by the researcher.

We also had one student participant called Paula. This is not her real name, just a nickname given to her in this study. She was an adult female student with an intellectual 
disability. Table 3 presents some relevant characteristics of the participating student Paula who is 29 years old, currently enrolled in elementary school.

\subsection{Organisation and teaching performance in the mainstream classroom}

The mainstream classroom was a large and well-ventilated space, with a blackboard, a worktable for the teacher, two lockers that were shared by the teachers on the respective shifts and 23 tables and chairs for the students. Because it is a multi-year room, the class was divided into two groups, that is, 6 students in the $1^{\text {st }}$ Term corresponding to the $1^{\text {st }}$, $2^{\text {nd }}$ and $3^{\text {rd }}$ year of elementary school $\mathrm{I}$, and 16 students in the $2^{\text {nd }}$ Term corresponding to the $4^{\text {th }}$ and $5^{\text {th }}$ year elementary school I and a 29-year-old student diagnosed with intellectual disability. The other students in the class were aged between 23 and 77 years old, 7 men and 15 women, most of the students were informal workers or retired. The Teacher worked on mathematical operations at the same time with the two groups, with different contents. The layout of the YAE classroom is shown in Figure 1.

Figure 1: Layout of the YAE classroom

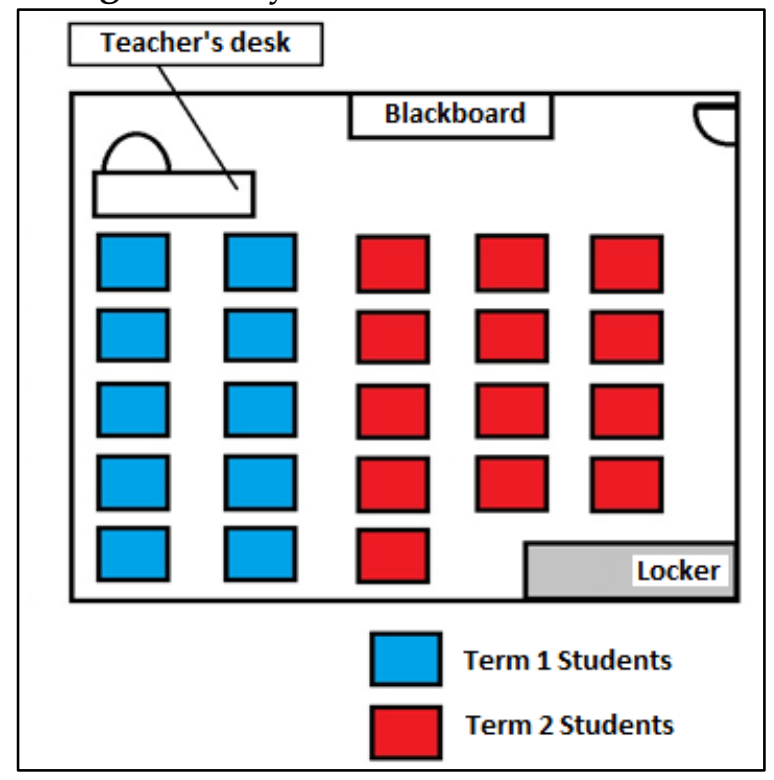

Source: Prepared by the author.

Regarding the routine of classes in the mainstream classroom, the teacher basically followed the same structure, that is, the contents of the Portuguese language and mathematics were worked on daily; the other subjects, sciences, history and geography were covered, on average, once a week.

The selection of content, in most cases, was made from the textbook adopted at the school that brought programmed content for each term of YAE. Based on the textbook, the teacher developed the classes following the structure of the book. The styles of the classes were the same for all students, that is, there was no adaptation for the student with disabilities or for other students with more needs.

The room was divided into two terms or groups, the difference was in the topics covered in each group and so the teacher normally divided the blackboard into two parts. 
On one part, the activity was related to Term 1 and the other part was related to Term 2. The explanations were collective and common for all students to pay attention to the explanations directed to both Terms, for example, while the teacher read a text for Term 1 , the students of Term 2 were concentrating and participating in the activities.

\section{"[...] you can't get much out of them, what they know, and you can't do that survey of what they know and what they think about writing and what they think about a certain number and where they use the function number, there is no way to get it out of them." (Mainstream Classroom Teacher)}

Still regarding the pedagogical practices of the Mainstream Classroom Teacher, the observations show the existence of difficulties in the explaining of the contents both for the student with intellectual disability and for the other students. According to the teacher, this difficulty only occurs because students do not have the minimum expected knowledge, so they need more objective activities to avoid feeling discouraged in the learning process.

"YAE alone is already difficult, you know, they come with very low self-esteem, they must deal with them, see the way to speak if they think they are being involved and they stop. You must be more direct and know how to deal with them, I focus more on reading and basic math operations. (Mainstream Classroom Teacher)

The teacher herself also recognises her difficulty in working with adult students with intellectual disabilities. For her, working with children with intellectual disabilities is easier for the reasons set out in her account below.

"[...] she is the first adult student in my life with this type of need, you know, with children it is easier because they no longer come with the pre-concept of learning and they are not afraid of making mistakes and they are less resistant and with the adult like her I felt this more difficult." (Mainstream Room Teacher).

In relation to the interaction, it is observed that the target student had a good level of socialisation and interaction with the other students in the class, always making comments on the issues that were discussed regarding the daily life of the neighbourhood or some event in the city. However, the teacher reports an initial resistance from the student to do the activities in addition to presenting difficulties in interacting with others. Therefore, we understand that, in the perspective of YAE with the great diversity of students that are part of this system, the planning and teaching and learning process is the responsibility of the school and not just the teacher. This work also defends the importance of an enabling environment for teachers to plan and organise the teaching situations that can meet the needs of students and benefit them all. 


\subsection{Organisation and teaching performance in the multifunctional resource room}

The multifunctional resource room had a good physical structure, a large space with good ventilation and good teaching material, such as games, toys, two round tables with 5 chairs and another table for the teacher's work. Although the school was relatively new, the multifunctional resource room functioned from the donations that the school received and collected for the Beneficent Bazaar to buy toys for children during holiday, such as on Children's Day and New Year's Eve.

Specialised educational assistance for the target student took place twice a week, lasting 60 minutes. The Special Education Teacher attended two students at the same time at a round table. They remained very close to the teacher and sometimes performed the same activities.

At the school there was only one Special Education Teacher, who attended all students targeting special education. The visits, according to the teacher, were almost always in pairs, but she also attended a group of 3 or 4 students. Although the teacher had no other occupation at school, at sometimes she had to help the principal, for example, when preparations were made for the town's birthday, the students were dismissed for 10 days and the teacher stayed in the resource room making props for the school parade. At other times, the attendance was also suspended so that the teacher could accompany the director on external visits in the community.

The student's attendance took place in parallel with a 9-year-old student with an intellectual disability. This grouping of students made it difficult for both to plan and develop the activities carried out in this space.

The Teacher of the Multifunctional Resource Room reports knowing a little about the school history of the target student. Even as an adult, it was possible to perceive that the teacher referred to the student Paula several times as a girl or a child and that she was unable to develop and acquire systematic knowledge related to literacy, because during the time she attended the Special School, the activities were more related to workshops than activities of pedagogical practices, according to the teacher, Paula

\section{"[...] she is a girl who spent her whole life at the Special School in the workshop, her literacy stopped there, she learned almost nothing, she knows as if the person was not going to learn anything else, so she starts to stimulate the workshop part and not learning like that, you know, at the Special School, they have another focus." (Special Education Teacher)}

According to the account of the Special Education Teacher, the special school emphasises literacy until a certain time, later, if it is identified that the student has not reached literacy, that is, if she/he cannot learn more academic content, the focus of the special school will be the workshops for preparing for the job market. The speech of the Special Education Teacher shows that the perception of the student's child characterisation was common in other contexts of the school. However, the Special Education Teacher also recognises the student's artistic ability to express herself through dance choreographies. 
"[...] Paula is a child; I see her as a 10-year-old girl. When we have a party here at school and there is music, for example, on children's day and if you saw it (laughs) we played children's music, you know, and those soap operas like Carousel and she dances very well. She dances and the children look and dance with her." (Special Education Teacher)

It is important to point out that, despite having a lower level of social interaction, according to the teacher, the student presented a good behaviour and great satisfaction for being at school.

"She is a very calm girl, right? She is a passive girl; she is not a quarrel or anything [...]. She says she loves school. She looks like she has gratitude you know; it looks like that she shows me. She doesn't know that she's showing gratitude, but she is." (Special Education Teacher)

Regarding the focus of the work in specialised educational assistance, the teacher reports the existence of a low self-esteem of the student when she started the services and the option to privilege activities focused on literacy, mainly related to reading. According to the teacher, it was possible to observe that there was an evolution on the part of the student, however, the teacher considers that the student has better and worse days.

"When she arrived the first thing, I realised is that she was not fully literate and she stagnated there at a stage you know and she herself thought she would not progress at all, and she knows when, by the way, she came with very low self-esteem and she thought that what she knows is the most she will learn." (Special Education Teacher)

The teacher points out a pedagogical work focused on important skills for the student's school and social context, such as literacy, especially the teaching of reading which is characterised as an activity seen as reinforcement of content, since literacy is placed as a principle in the mainstream classroom.

Regarding pedagogical practice, the Teacher of the Multifunctional Resources Room, says to seek and always identify the best way for the student to acquire knowledge. In the case of student Paula, she believes that the exploration of the tangible used more at the beginning of the consultations was an important aid for the realisation of this process that was dormant, according to her, due to the type of activity that was offered to the student at the Special School. The teacher also reports how the activities with the student work, demanding that they be executed until they are in accordance with what was expected by the teacher.

\subsection{Interaction between the Mainstream Classroom Teacher and the Special Education Teacher at YAE}

Thinking about pedagogical practices and the inclusion of students with disabilities makes us reflect on the possibilities of teaching practice among teachers in the 
mainstream classroom and in special education. Thus, the interaction of these educators when effective can favour the process of school inclusion of these students as it strengthens the collaboration between those involved in schooling.

However, the schools' daily routine points out that this interaction is not always possible, as the meetings take place as informal moments, not intended for the discussion and preparation of the educational planning of the students together. Thus, each teacher carries out his planning individually and without the knowledge of the organisation and the development of the curriculum of the other.

"It is what it follows and as it does we cannot know or meet to discuss the planning, I try to catch the planning and, to sometimes, as much as I can do so with the Mainstream room teacher is talking to her in the corridor and that's the truth, we don't do any makeup right, so what I do is try to see the YAE planning, see the content and what is expected for that year and try to work on these themes with Paula." (Special Education Teacher)

One of the barriers pointed out by teachers for this partnership is related to the lack of a timetable for school coordination to provide an adequate time for discussion and planning. Linked to this, there is the high workload of these professionals, who often assume other employment links to supplement wage income. This lack of coordination in the combination of these schedules does not favour a culture of collaboration, which, consequently, makes it more likely to limit the interaction of teachers due to the working conditions existing in schools. A viable alternative would be to have a greater number of special education teachers to serve the school's Specialised Education Service Teachers (SEST) students.

"I work in three schools, three shifts, now it would be my HTPC", this time she (the Special Education Teacher) is in the office hours, she would be attending a child, there is no way for us to meet, in her HTPC I am working, we can't meet, uh. I think I saw her (the Special Education Teacher) about three times, always in the hall. Think about the dynamics, it doesn't exist, you know, people who go for a walk, you know? She tries to do this, to do that, to do that I don't know what to do there, but she must suspend the students' services." (Mainstream Room Teacher).

Certainly, the Specialised Educational Service should not assume a proposal for reinforcement or even serve as a substitute for the mainstream classroom. The teacher of the Specialised Educational Service seeks to meet the specific needs of the student by developing pedagogical resources and strategies to promote access to knowledge. However, this performance must assume a relationship with the curriculum of the mainstream classroom, which involves the development of supports, enabling the

\footnotetext{
ii HTPC is Collective Pedagogical Work Schedule. Within the teacher's workday, two thirds of his workload must be completed in the classroom and another third of time is devoted to extra-class pedagogical activities, so that the teacher plans his classes and improves the pedagogical practice.
} 
student to overcome the barriers that impede his/her access to the curriculum. In this sense, the Specialised Educational Service is linked to the syllabus of the mainstream classroom and must be organised with the necessary adaptations and ensuring the strategies and resources to promote learning.

\section{Discussion and Conclusion}

Regarding planning at YAE, the study agrees with Trentin (2018) when arguing that the activities should be organised aiming at the learning of all students and not only those with intellectual disabilities. Through this reality, planning helps because it guides the actions of teachers, that is, it offers a direction on how to conduct pedagogical practices and how to organise learning situations. In this sense, it is important to reaffirm that the contents of school planning must dialogue with what is taught to students in general and, based on this, teachers should think about teaching strategies for the development of students with intellectual disabilities considering their level of education. development, age group and interests (Glat; Vianna; Redig, 2012).

On the inclusion of disabled students in adult education, Redig (2010) states that even this mode being made, essentially, by a student body with very different characteristics from one to another, still prevails the lack of recognition of the common school teachers to receive these students on the grounds of who knows how to handle this students. One of the difficulties mentioned also by teachers who work at YAE with students with intellectual disabilities concerns the difficulties in working with these students both in the contexts of interaction and in the pedagogical scope.

According to the mainstream classroom teacher, YAE students, in general, have greater difficulty in expressing their opinions and have a low interest in participating in the proposed activities; besides the little school knowledge they have. Given these findings, Bueno and Oliveira (2019) state that the teacher is the mediator between the student and the syllabus. In this sense, teachers who work at YAE need to understand that "the schooling process must become significant, influence the change of paradigms and overcome old social concepts regarding adult development, as the stereotype of a tutored life." (Bueno \& Oliveira, 2019, p.13).

The representation of adults with intellectual disabilities seen as a permanent child is discussed by Dias and Oliveira (2013) and Freitas (2014), indicating that many adults with intellectual disabilities receive the same pedagogical treatment that is intended for children in the school and social context, that is, there is no differentiated practice for these subjects. That is why it is necessary to recognise the educational and social space of these students as adults and that they can develop specific skills for their age, this means, that the practices developed must meet and the specific possibilities and demands for the life span of the student

The conception that the student did not develop as an adult is noted by the teacher's speech and attitudes. Kassar (1999) points out that, often, the idea of this social representation of adults with disabilities is reinforced by specialised professionals when 
they assume and develop their pedagogical actions based on children's and repetitive activities. According to Trentin (2018, p. 80), the young and adult student of YAE, in the course of life, has already acquired different knowledge than what children have. Such knowledge "[...] needs to be considered in schooling so that these subjects feel part of the educational context". However, reflections on the specificities of these subjects inserted in the YAE are still lacking.

The analysis of the observations in the multifunctional resource room made it possible to understand important aspects about the development of the pedagogical practice of the Special Education Teacher. The teacher reports the initial difficulty of working with Paula, because for her, the student had all the potential, but she was asleep. For the development of the student, the teacher initially worked with concrete material and help to solve the proposed activities. The teacher also mentions the degree of demand that she has in the development of activities, and the oscillation that exists in the development of the student with better and worse days.

In the daily routine of MRR classes, it was possible to see the development of several children's activities to be used for the different students who attended the SES, however the teacher in the resource room had only Paula as an adult student. These activities were almost always printed in larger quantities to be used by other students as well, as they were small texts; words associated with images; crosswords; activities of linking writing to the figure of the object; find words; form simple sentences created by the student with the help of the teacher from a keyword; reading cards; sayings; copy of words and exercises involving mathematical operations (addition, subtraction and multiplication). These were expository classes followed by exercises written in the notebook, that is, no methodological changes were observed.

Research such as by Dantas (2012), Freitas (2014) and Mamcasz-Viginheski (2017) affirm that the teaching conceptions remain strongly marked by the belief that the adult is not able to behave as an adult. The simplification of the content resulting in activities originally intended for children can be an alternative to promote development and to reduce the difficulty of teachers in adapting activities for young and adult students of YAE. For Almeida (2017), it is necessary to overcome teaching cantered on disability, believe and value the ability of students with disabilities to advance in the learning process.

However, it was not possible to observe or identify any adaptation for the target student, since the same activities were also prepared for the other students with different disabilities who attended the SES. It should be noted that, in this case, there could be some differentiation in the development of these activities, which was not the target of our study object. It was found the use of a resource prepared by the teacher, called by the Teacher of the Multifunctional Resource Room as "list", to assist the student when writing complex words.

Regarding the attendance of the target audience of special education students, it should be noted that, according to the school team, the educational process of this student is still restricted to Specialised Educational Service, that is, in this mistaken perspective 
on the legal aspects of education. In particular, the responsibility for schooling lies with the special education teacher. Specialised Educational Service is one of the support services for students targeting special education that must be provided for in the school's pedagogical proposal. (Oliveira, Cordeiro, \& Machado, 2018).

According to the guidelines of Specialised Educational Service, the performance of the teachers in the multifunctional resource rooms acquires a collaborative perspective with the teacher of the mainstream classroom, since among other duties this articulation is foreseen with the purpose of promoting the participation of students in school activities. However, each teacher has a different role; the teacher of the mainstream classroom is assigned the teaching of the areas of knowledge, while the teacher of the multifunctional resources room develops the complementation and / or supplementation "[...] the training of students with a view to autonomy and independence at school and out of it." (Brasil, 2009, p.1).

Regarding the practices directed to the teaching of mathematics, the observations revealed an emphasis on exercises involving operations of addition, subtraction and multiplication by a single number. The exercises were organised in the form of accounts for solving the student, in addition to the sequential writing of ordinal numbers. As a resource to facilitate the resolution of exercises involving multiplication, for example, the student consulted a table with the data and with the help of the teacher finds the number to be multiplied and its respective result; when she had to advance a dozen, the teacher helped to count on her fingers to arrive at the correct answer.

According to Decree $N^{\circ} 6,571$ of 2008, the work developed within the Specialised Educational Assistance (SES) must provide the SEST student with appropriate conditions for their development, as shown in the regulation in its article according to:

Art. 2 The objectives of specialised educational assistance are:

i. provide conditions for access, participation and learning in mainstream education to the students referred to in art. 1st;

ii. guarantee the transversality of special education actions in mainstream education;

iii. encourage the development of didactic and pedagogical resources that eliminate barriers in the teaching and learning process; and

iv. ensure conditions for the continuity of studies at other levels of education. (Brazil, 2008a)

This report validates an understanding in which it is stated that people with intellectual disabilities can develop as the pedagogical proposals are carried out both in the SES and in the mainstream classroom, as they can contribute to the teaching and learning process and, therefore, for student development. Therefore, the need to develop a collaborative work is emphasised, mainly between the teacher of the mainstream classroom and the teacher of the SES. It should also be noted that in the context of the school surveyed, teachers carried out their literacy work in isolation and in different ways.

Some studies like, Mendes; Almeida; Toyoda (2011); Mendes; Vilaronga ; Zerbato (2014) indicate that collaboration between teachers of special education and regular 
education, when carried out, benefits both students and teachers, as it involves the development of a strategy of mutual support between teachers in the search for solving problems related to learning barriers. Studies show that the engagement of professionals makes the environment more favourable for the process of inclusion and development of students.

Also, this report allows us to understand that the work of the Teacher of the Multifunctional Resource Room occurs in isolation from the Teacher of the Mainstream Classroom, there is no relationship of dialogue that allows the development of partnership and planning between the teachers, as well as the lack of knowledge about the work and the development of the student himself. Therefore, the educational planning process, the exchange of information about the student becomes non-existent. For Mendes, Vilaronga and Zerbato (2014), although the resource room is a service provided for in the Brazilian inclusion policy and is widely used, it does not favour the sharing of responsibilities related to the students' schooling process.

This report considers it relevant to reflect, critically, on the pedagogical practices for adult students with intellectual disabilities, as the results proved the infantilised character and incapacitating vision that still permeates the pedagogical actions aimed at these students. In addition, the lack of articulation of specialised educational assistance with the classroom and the absence of a school organisation model that favours planning actions among teachers and even the actions that are developed in these spaces do not play a role in the development of education of students. Therefore, reflecting on the pedagogical performance can produce a movement of a new posture in face of the challenges posed to the schooling of these students.

\section{Conflict of interest statement}

No conflict of interests has been declared.

\section{Funding source}

This study was supported in part by the Ministry of Science, Technology, Innovation and Communications (CNPq) case number 132750 / 2018-0.

\section{Ethical approval}

CSES approved project 9.6311618.5.0000.5504 granted by the Ethics Committee in Research with Human Beings of the Federal University of São Carlos - UFSCar - Brazil. All participants agreed to participate in the research and signed the consent form.

This research was undertaken with the understanding and written consent of each participant and according to the mentioned principles here (https://www.wma.net/policies-post/wma-declaration-of-helsinki-ethical-principles-formedical-reSESrch-involving-human-subjects/). 


\begin{abstract}
About the Authors
Graciliana Garcia Leite graduated in Special Education at the Federal University of São Carlos (UFSCar). Specialization in Diversity and Inclusive Education in the Context of Science from the Federal University of Mato Grosso (UFMT) and Specialization in People Management and Social Projects from the Federal University of Itajubá (UNIFEI). Master in Special Education from the Federal University of São Carlos (UFSCar) and PhD student at the same institution. Graduate in Pedagogy from the State University of São Paulo (UNESP) Campus of Araraquara.

Juliane A. Paula Perez Campos PhD graduated in Special Education from the Federal University of São Carlos (2006), Master in Special Education from the Federal University of São Carlos (1999), Graduation in Psychology from the Federal University of Uberlândia (1996), and Graduation in Pedagogy from the Centro Universitário Claretiano (2006). Associate Professor, Department of Psychology, Federal University of São Carlos (beginning in 2009). Acts as a teacher in the Special Education Degree course and in the Special Education Graduate Program. In addition to teaching, it develops research and extension activities, mainly in the following themes: special education, teacher training, intellectual disability, didactics and pedagogical practices in an inclusive context, special education in the context of high school and the education of young people and adults, professionalization of people with disabilities.
\end{abstract}

\title{
References
}

Bins, K. L. G. (2013). Adultos com deficiência intelectual incluídos na educação de jovens e adultos: apontamentos necessários sobre adultez, inclusão e aprendizagem. [Adults with intellectual disabilities included in youth and adult education: necessary notes on adulthood, inclusion and learning]. Unpublished PhD thesis. Pontifícia Universidade Católica do Rio Grande do Sul.

Brasil. Lei n. 9394, de 20 de Dezembro de 1996 [of December 20, 1996]. Estabelece as Diretrizes e Bases da Educação Nacional. Diário Oficial da União, Brasília, DF, 23 dez. 1996 [Establishments of the guidelines and bases for national education. Federal Official Gazette, Brasília, DF, December 23. 1996]. Available on: http://www.planalto.gov.br/ccivil 03/leis/L9394.htm. (Accessed on: 12 April 2018).

Brasil. Ministry of Education (2008). Politica nacional de educação especial na perspectiva da educação inclusiva [National special education policy from the perspective of inclusive education]. Available on: http://portal.mec.gov.br/arquivos/pdf/politicaeducespecial.pdf (Accessed on: 12 April 2018).

Brasil. Ministry of Education (2009). Resolution no 4/2009. Institui diretrizes operacionais para o atendimento educacional especializado na educação básica, modalidade 
educação especial [Institutes operational guidelines for specialised educational assistance in basic education, special education modality]. Brasília: SEESP.

Bueno, O. M. and Oliveira, R. C. S. (2019). O desenvolvimento adulto do sujeito deficiente intelectual e a relação com a Educação para Jovens e Adultos (EJA): uma análise, a partir da perspectiva docente, [The adult development of the person with intellectual disability and the relationship with Education for Youth and Adults (EYA): an analysis, from the teaching perspective], Revista Educação Especial, 33(3), 1-15. Available on: https://periodicos.ufsm.br/educacaoespecial/article/view/3020 (Accessed on: 1 August 2018).

Cabral, R., Bianchini, L. and Gonçalves, T. (2018). Educação especial e educação de jovens e adultos: uma interface em construção?, [Special education and youth and adult education: an interface under construction?], Revista Educação Especial, 31(62), 587602. Available on: https://periodicos.ufsm.br/educacaoespecial/article/view/30841 (Accessed on: 9 June 2020).

Cezário, A. P. B. (2019). Atendimento educacional especializado e a educação de jovens e adultos: arte e estéticas inclusivas [Specialised educational assistance and the education of young people and adults: art and inclusive aesthetics]. Master's Degree. Universidade Estadual Paulista. Available on: https://repositorio.unesp.br/bitstream/handle/11449/181342/cezario apb me bau ru sub.pdf?sequence $=5$ (Accessed on: 5 February 2020).

Dantas, D. C. L. (2012). A inclusão de pessoas com deficiência intelectual na educação de jovens e adultos EJA: um estudo de caso [The inclusion of people with intellectual disabilities in youth and adult education YAE: a case study]. Unpublished PhD thesis. Universidade Federal do Rio Grande do Norte.

Decree $n^{\circ} 6.571 / 2008$. Dispõe sobre o atendimento educacional especializado [Order for specialised educational assistance]. Available on: https://www2.camara.leg.br/legin/fed/decret/2008/decreto-6571-17-setembro2008-580775-publicacaooriginal-103645-pe.html (Accessed on: 3 August 2019).

Dias, S. S. and Oliveira, M. C. S. L. (2013). Deficiência intelectual na perspectiva históricocultural: contribuições ao estudo do desenvolvimento adulto, [Intellectual disability in the historical-cultural perspective: contributions to the study of adult development], Revista Brasileira de Educação Especial, 19(2), 169-182. Available on: http://www.scielo.br/scielo.php?script=sci arttext\&pid=\$141365382013000200003 \&lng=en\&nrm=iso (Accessed on: 6 February 2019).

Franco, M. L. P. B. (2008). Análise de conteúdo. 3rd edn. Brasília: Liber Livro Editora.

Freitas, M. A. S. (2014). Estudantes com deficiência intelectual na educação de jovens e adultos: interfaces do processo de escolarização [Students with intellectual disabilities in youth and adult education: interfaces of the schooling process]. Unpublished Master's Degree. Universidade Federal de São Carlos.

Lei no 9.394/1996. Estabelece as diretrizes e bases da educação nacional [Establishes the 
guidelines and bases for national education]. Available on: http://portal.mec.gov.br/seesp/arquivos/pdf/lei9394 ldbn1.pdf (Accessed on: 8 June 2019).

Mascaro, C. A. A. C. (2017). O atendimento pedagógico na sala de recursos sob o viés do plano educacional individualizado para o aluno com deficiência intelectual: um estudo de caso [Pedagogical assistance in the resource room under the bias of the individualised educational plan for students with intellectual disabilities: a case study]. Unpublished PhD thesis. Universidade do Estado do Rio de Janeiro.

Mendes, E. G.; Vilaronga, C. A. R.; Zerbato, A. P. (2014). Ensino Colaborativo: unindo esforços entre educação comum e especial' [Collaborative Teaching: joining efforts between common and special education]. São Carlos: EdUFSCar, .

Oliveira, M., Cordeiro, N. D. and Machado, A. F. (2018). O que pensam as equipes diretivas escolares sobre o atendimento educacional especializado (AEE), [What school management teams think about specialised educational assistance (SEA)], Educação em Revista, 34(epub 19). Available on: http://www.scielo.br/scielo.php?script=sci arttext\&pid=S010246982018000100135\&lng=pt\&nrm=iso (Accessed on: 18 November 2019).

Pletsch, M. D. (2014). A escolarização de pessoas com deficiência intelectual no Brasil: da institucionalização às políticas de inclusão (1973-2013), [Schooling for people with intellectual disabilities in Brazil: from institutionalization to inclusion policies (1973-2013)], Revista Arquivos Analíticos de Políticas Educativas, 81(22). Available on: https://epaa.asu.edu/ojs/ (Accessed on: 12 February 2018).

Pletsch, M. D. and Glat, R. (2012). A escolarização de alunos com deficiência intelectual: uma análise da aplicação do Plano de Desenvolvimento Educacional Individualizado, [Schooling of students with intellectual disabilities: an analysis of the application of the Individualised Educational Development Plan], Linhas Críticas, 18(35), 193-208. Available on: https://www.redalyc.org/pdf/1935/193523804012.pdf (Accessed on: 12 February 2018).

Redig, A. G. (2019). Caminhos formativos no contexto inclusivo para estudantes com deficiência e outras condições atípicas, [Training paths in an inclusive context for students with disabilities and other atypical conditions], Revista Educação Especial, 32 , 1-19. Available

on: https://periodicos.ufsm.br/educacaoespecial/article/view/35721/35721 (Accessed on: 19 October 2019).

Reis, P. (2011). Observação de aulas e avaliação do desempenho docente [Class observation and teacher performance evaluation]. Lisboa: Ministério da Educação. Available on: https://repositorio.ul.pt/bitstream/10451/4708/1/Observacao-de-aulas-e-avaliacaodo-desempenho-docente.pdf (Accessed on: 27 August 2020).

Siems, M. E. R. (2012). Educação de jovens e adultos com deficiência: saberes e caminhos em construção, [Education of young people and adults with disabilities: knowledge and paths under construction], Educação em Foco, 16(2), 61-79. 
Available on: http://www.uff.br/revistaedufoco/files/2012/08/Texton-031.pdf (Accessed on: 12 March 2018).

Strelhow, T. B. (2010). Breve história sobre a educação de jovens e adultos no Brasil', [Brief history of youth and adult education in Brazil], Revista HISTEDBR On-line, 10(38), 49-59. Available on: https://periodicos.sbu.unicamp.br/ojs/index.php/histedbr/article/view/8639689 (Accessed on: 9 June 2020).

Trentin, V. B. (2018). Escolarização de jovens com deficiência intelectual na educação de jovens e adultos (EJA). [Schooling of young people with intellectual disabilities in youth and adult education (YAE)]. PhD thesis. Universidade do Vale do Itajaí. Available on: https://docplayer.com.br/115777338-Valeria-becher-trentinescolarizacao-de-jovens-com-deficiencia-intelectual-na-educacao-de-jovens-eadultos-eja.html (Accessed on: 20 February 2018).

Vargas, P. G. and Gomes, M. F. C. (2013). Aprendizagem e desenvolvimento de jovens e adultos: novas práticas sociais, novos sentidos, [Learning and development of youth and adults: new social practices, new meanings], Educação e Pesquisa, 39(2), 449-463.

Available

on:

http://www.scielo.br/scielo.php?script=sci arttext\&pid=S151797022013000200011\&lng=en\&nrm=iso (Accessed on: 16 May 2020). 

be applied to their work. Under the terms of this license, no permission is required from the author(s) or publisher for members of the community to copy, distribute, transmit or adapt the article content, providing a proper, prominent and unambiguous attribution to the authors in a manner that makes clear that the materials are being reused under permission of a Creative Commons License. Views, opinions and conclusions expressed in this research article are views, opinions and conclusions of the author(s). Open Access Publishing Group and European Journal of Special Education Research shall not be responsible or answerable for any loss, damage or liability caused in relation to/arising out of conflict of interests, copyright violations and inappropriate or inaccurate use of any kind content related or integrated on the research work. All the published works are meeting the Open Access Publishing requirements and can be freely accessed, shared, modified, distributed and used in educational, commercial and non-commercial purposes under a Creative Commons Attribution 4.0 International License (CC BY 4.0). 